\title{
TYPE COMPOSITION OF EEL SEED (ANGUILLA SPP.) IN DUMOGA CREEK, BOLAANG MONGONDOW
}

\author{
Kusuma Ni Putu Dian*, Herawati Endang Yuli, Sambah Abu Bakar \\ Master's Program in Aquaculture, Postgraduate Program, University of Brawijaya, Indonesia \\ ${ }^{*}$ E-mail: ndkbluefin89@gmail.com
}

\begin{abstract}
Dumoga River is one of the rivers in Bolaang Mongondow Regency disembogue to the Sulawesi Sea which becomes the entrance of glass eel from the sea. Glass eel that enters the river consists of several species. The purpose of this study was to study the species composition of glass eel that migrates to the creek of the Dumoga River. Glass eels were collected at the creek from 20th of April 2018, to 30th of May 2018 at 00:00 to 04:00. In a period of 40 days, there were 2,251 glass eels collected and consist of 3 species namely Anguilla marmorata (49.13\%), Anguilla bicolor pacifica (37.94\%), and Anguilla spp. (12.93\%). Glass eels are stored in formalin for morphometric and meristic measurements. Morphometric was done by calculating the $A D$ value (DA $=100$ (LD-LA) LT-1) and the tail pigmentation structure. Meristic was done by calculating the eyelid spine. The result showed that the value of $A D$ obtained ranged from (0-2.87) grouped in the type of bicolor pacifica, $(14.90 \%-16.14 \%)$, grouped in the type A. marmorata and $(6.85 \% 7.21 \%)$ grouped in the Anguilla sp.
\end{abstract}

\section{KEY WORDS}

Glass eel, Dumoga River, Anguilla bicolor pacifica, Anguilla marmorata, Anguilla sp.

Eel fish (Anguilla spp.) has a unique variety aspect of biology that become a mystery until today. The fish has a catadromous lifecycle pattern that starts their lives at the sea, migrates into freshwater to grow up and will migrate back into the sea for spawning (Tesch et al., 2003). Therefore, the migration of the eel larvae to the river is always through the creek. The eels' larva migrates from the spawning sites in the deep-sea area to the river that disembogue to the deep sea, including the Dumoga River.

There are nine species/subspecies in Indonesia of the twenty-two species/subspecies of eels found in the world, Anguilla celebesensis, A. interioris, A. nebulosa nebulosa, A. marmorata, A. borneensis, A. bicolor bicolor, A. bicolor pacifica, A. obscura and A. megastoma (Sugeha and Suharti, 2008). Identification of eel fish species found on the Dumoga River has been done previously by Novianti (2007) and Fahmi (2015). There are four species found, namely A. marmorata, A. bicolor pacifica, A. celebesensis and Anguilla spp.

Dumoga River becomes one of the potential sites of eel fish because it is close to the spawning location. The spawning sites of $A$. borneensis and A. celebesensis are located in the high seas of Sulawesi and Tomini Bay (Central Sulawesi) because they lay more in the deep sea close to their juvenile habitats (Aoyama et al., 2003; Ishikawa et al., 2004 ), while spawning sites of A. marmorata and A. bicolor pacifica are located in the western part of the North Pacific (Miller et al., 2002; Sugeha and Arai, 2010; Arai, 2014).

Yet, it has a lack of scientific information about the migration of eel larvae entering to the mouth of the Dumoga. Thus, the typical composition of eel larvae that migrate to the mouth of the Dumoga River is also unknown. This study aims to identify the type and abundance of glass eel phase eel larvae that enter the mouth of the Dumoga River.

\section{METHODS OF RESEARCH}

The study was conducted on April 23 - May 26, 2018. The sample collection of glass eel larvae phase was conducted at the mouth of Dumoga River, Bolaang Mongondow District 
(Coordinate $0.922556^{\circ} \mathrm{E}-124.090733^{\circ} \mathrm{E}$ ) at $00.00-04.00$ ICST. Glass eel of fisherman catch is identified at Freshwater Aquaculture Laboratory (BPBAT) Tatelu.

The materials used in this study consisted of $95 \%$ alcohol, $75 \%$ formalin and glass eel larvae phase. The eels' larvae is collected at the edges of the river by shifting using $60-100$ $\mathrm{cm}$ sized-net. The collection of the eel larvae is carried out by sweeping the entire area (transects along 20 meters and 1 meter wide) by shifting for 10 times back and forth. Thus, the sample area of $200 \mathrm{~m} 2$ is obtained.

The eels' larva obtained then fed into the formalin for morphological analysis. Morphometric measurements and tail pigmentation determinations were performed using a digital caliper with an accuracy of $0.01 \mathrm{~mm}$ under a stereomicroscope equipped with a digital camera and a computer for shooting. The determination of glass eel type based on morphometric refers to Elis (1982) in Reveillac et al., (2009), are anal length (AL), dorsal length (DL) and total length (TL), ano-dorsal value (AD) with the following equation:

$$
A / D \%=\frac{(L D-L A)}{L T} \times 100
$$

\section{RESULTS OF STUDY}

Based on the morphological measurement, the total length of the glass eel at Dumoga River creek is divided into three groups: group with total length of $49.3 \mathrm{~mm} ; 58.29 \mathrm{~mm}$; and $73.31 \mathrm{~mm}$. In this study, it is obtained the value of AD which is divided into 3 groups namely $0 \%-2.87 \% ; 14.90 \%-16.14 \%$; and $6.85 \%-7.21 \%$. Referring to the grouping of eels based on $A D$ values, it is suspected that the type of eel that enters the mouth of the Dumoga River is Anguilla marmorata, Anguilla bicolor pacifica, and which has not been identified as Anguilla sp.

The data presented in Tables 1 and 2 show an association between the number of ano-dorsal vertebrae and the ano-dorsal length. Watanabe (2003) in the diagram of the phylogenetic tree explains that the total vertebra of $A$. bicolor is $105-111$ while the number obtained in this study is 111 . Meanwhile, the type A. marmorata is 103-110. In this study, it is obtained the value of 105. The total number of vertebrates' type of Anguilla sp. is 100-106. The calculation has obtained the value of 104 (Table 2).

Table 1 - Morphometric measurements of eel in glass eel phase

\begin{tabular}{|l|c|c|c|c|}
\hline \multicolumn{1}{|c|}{ Species } & $\mathrm{TL}(\mathrm{mm})$ & $\mathrm{DL}(\mathrm{mm})$ & AL $(\mathrm{mm})$ & Ano-dorsal $(\%)$ \\
\hline A. marmorata & 49.3 & 21.4 & 13.72 & 15.57 \\
\hline & $(44.50-54.10)$ & $(18.05-24.75)$ & $(11.42-16.02)$ & $(14.90-16.14)$ \\
\hline A. bicolor pacifica & 58.29 & 24.93 & 24.24 & 1.18 \\
\hline & $(48.02-68.55)$ & $(18.66-31.20)$ & $(18.66-29.82)$ & $(0-2.87)$ \\
\hline Anguilla sp. & 73.31 & 31.3 & 26.1 & 7.09 \\
\hline & $(50.65-95.96)$ & $(19.35-43.24)$ & $(15.88-36.32)$ & $(6.85-7.21)$ \\
\hline
\end{tabular}

Table 2 - Meristic measurements of eel in glass eel phase

\begin{tabular}{|l|c|c|c|c|}
\hline \multicolumn{1}{|c|}{ Species } & $\begin{array}{c}\text { Total of } \\
\text { spine }\end{array}$ & $\begin{array}{c}\text { Pre-dorsal } \\
\text { spine }\end{array}$ & $\begin{array}{c}\text { Pre-anal } \\
\text { spine }\end{array}$ & $\begin{array}{c}\text { Ano-dorsal } \\
\text { spine }\end{array}$ \\
\hline A. marmorata & $\begin{array}{c}105(104- \\
106)\end{array}$ & $18(17-19)$ & $37(36-39)$ & $18(18-20)$ \\
\hline A. bicolor pacifica & $\begin{array}{c}111(108- \\
112)\end{array}$ & $34(34-36)$ & $36(32-39)$ & $1(0-3)$ \\
\hline Anguilla sp. & $\begin{array}{c}104(100- \\
106)\end{array}$ & $28(27-29)$ & $32(30-33)$ & $7(6-12)$ \\
\hline
\end{tabular}

The observations were also made on the structure of tail pigmentation. The tail pigment of the eel larvae reaching the tip with a slightly rounded tail shape is categorized as Anguilla marmorata eel type. The pigment in Anguilla bicolor pacifica is shaped like a broom/brush. 
While in Anguilla sp., the shape of the tailbone is more similar to Anguilla marmorata with broom-shaped pigment as in Anguilla bicolor pacifica, but more pale and less dense.

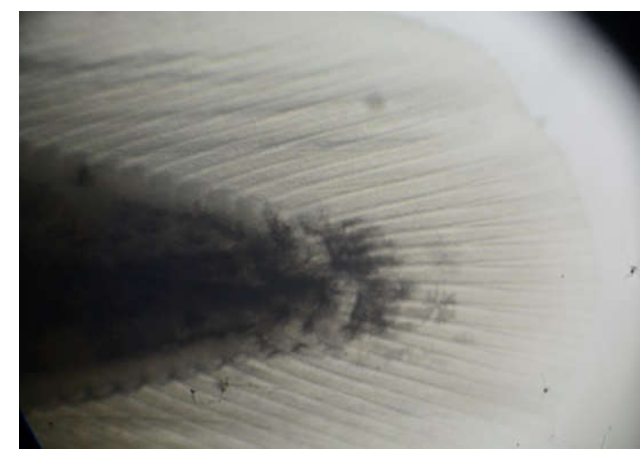

Figure 1 - Pigmentation of eel tail of Anguilla marmorata

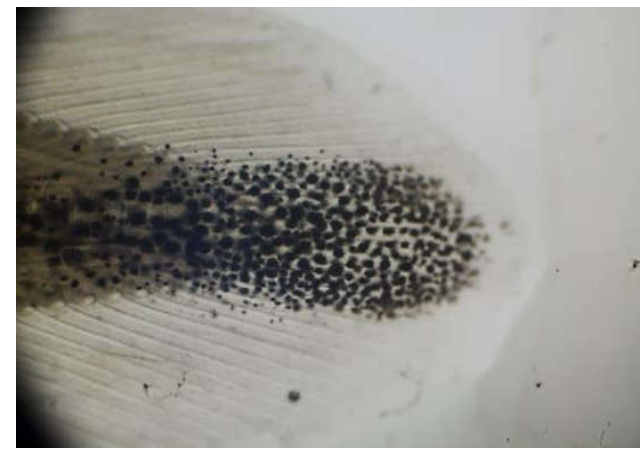

Figure 2 - Eel pigmentation of Anguilla bicolor pacifica

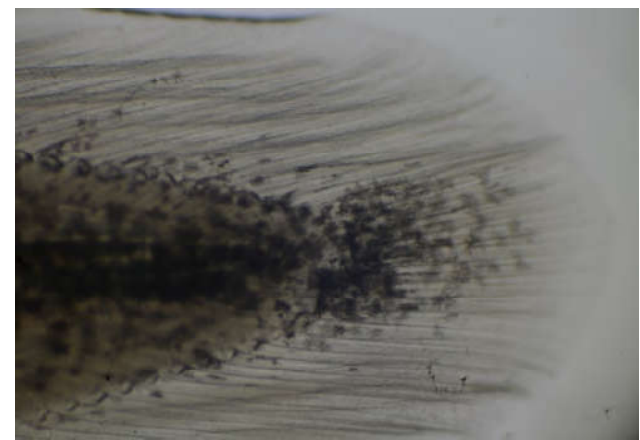

Figure 3 - Pigmentation structure in eel tail of Anguilla sp.

Comparison of pre-anal and pre-dorsal distances also characterizes differentiation between species of eels. Figure 4 shows the long-fin type of Anguilla marmorata because the pre-anal distance is shorter than pre-dorsal. While the fin-type on Anguilla bicolor pacifica type can be seen in Figure 5.

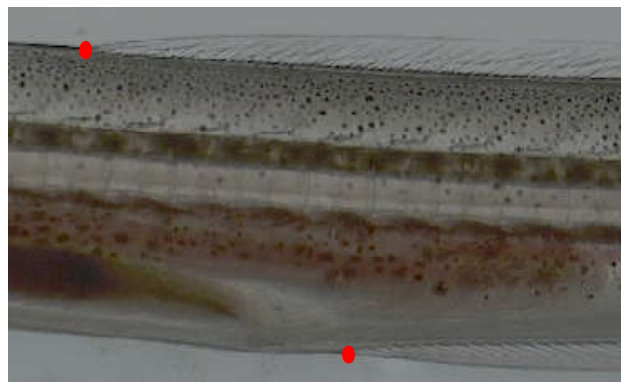

Figure 4 - Long fin characterization of Anguilla marmorata 


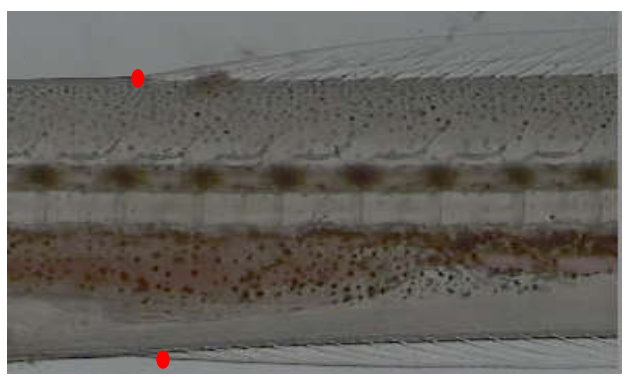

Figure 5 - Characterization of short fin on Anguilla bicolor pacifica

The eel phase observed during 40 days of research were 21251 tails. A total of $49.13 \%$ were thought to be Anguilla marmorata, $37.94 \%$ were Anguilla bicolor pacifica, and $12.93 \%$ were Anguilla.

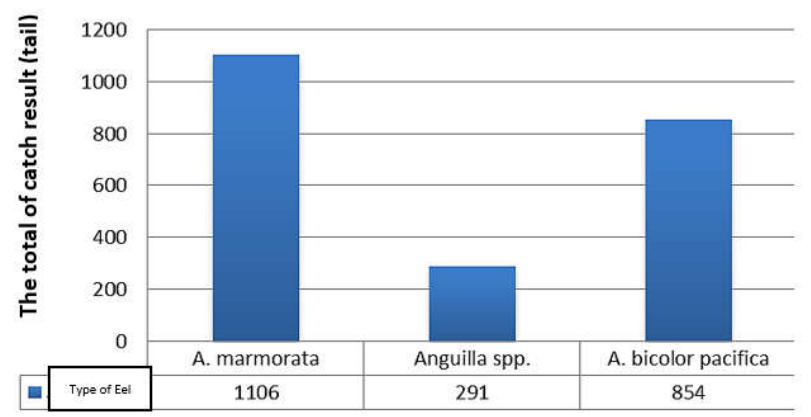

Figure 5 - Amount of eel catch at Dumoga River creek

Table 3 - The abundance of eel species

\begin{tabular}{|r|l|r|r|}
\hline No & \multicolumn{1}{|c|}{ Type of Eel } & $\begin{array}{c}\text { K } \\
\text { (Individual) }\end{array}$ & $\begin{array}{c}\text { KR } \\
\text { (\%) }\end{array}$ \\
\hline 1 & A. marm orata & 1106 & 49.13 \\
\hline 2 & Anguilla spp. & 291 & 12.93 \\
\hline 3 & A. bicolor pacifica & 854 & 37.94 \\
\hline \multicolumn{2}{|c|}{ Total } & 2251 & \\
\hline
\end{tabular}

The waters quality data of Dumoga river creek during the research can be seen in Table 4. The data shows that the waters of Dumoga river are ideal waters for the environment of eel fish.

Table 4 - Water quality measurement results

\begin{tabular}{|c|c|c|c|c|c|}
\hline Repetition & $\begin{array}{c}\text { Temperature } \\
(\mathbf{c})\end{array}$ & $\mathrm{DO}(\mathrm{mg} / \mathrm{L})$ & $\mathbf{N H}_{\mathbf{3}}(\boldsymbol{\mu g} / \mathbf{L})$ & $\mathbf{P O}_{4}{ }^{3-}(\mathbf{m g} / \mathbf{L})$ & $\mathbf{p H}$ \\
\hline 1 & 26 & 6 & 0.18 & 1.7 & 7 \\
\hline 2 & 26 & 6 & 0.2 & 1.7 & 6.8 \\
\hline 3 & 26 & 6 & 0.21 & 1.7 & 6.5 \\
\hline 4 & 26 & 6 & 0.18 & 1.7 & 7 \\
\hline Average & 26 & 6 & 0.19 & 1.7 & 6.8 \\
\hline
\end{tabular}

\section{DISCUSSION OF RESULTS}

During the 40-day sampling, the glass eels collected from the creek of the Dumoga River are dominated by A. marmorata and A. bicolor pacifica. This is in accordance with the statement of Ndobe et al., (2010) that A. marmorata and A. bicolor are suitable as seeds for cultivation of eels since the two species are found in large quantities varied with no clear seasonal and yearly patterns. In addition to A. marmorata and A. bicolor pacifica, it is also found a type of glass eel with low or very low $A D$ value of Anguilla sp. The following 
paragraphs will discuss the distribution of three species found at the mouth of the Dumoga River.

The Distribution of Anguilla bicolor pacifica. Type A. bicolor is divided into two subspecies namely $A$. bicolor bicolor and A. bicolor pacifica. Allopathic isolation (geographical isolation) between two oceans may have split $A$. bicolor into two subspecies. A. bicolor pacifica is widely distributed but less abundant. According to Wouthuyzen et al., (2009) the spawning area of A. bicolor pacifica occurs in the North Sulawesi Sea. Arai et al., (1999) states that glass eel A. bicolor pacifica can only be sampled in January, March, April, October, and December. The spawning area of A. bicolor pacifica appears to be unidentified. However, the current species distribution map by Aoyama (2009) and Fahmi et al. (2102) shows that both A. marmorata and A. bicolor pacifica are carried from the Sulawesi Sea.

Analysis of the population structure of $A$. bicolor pacifica shows no significant genetic differences in the distribution of the South Pacific Ocean (Minegishi et al., 2012). The wide distribution of $A$. bicolor pacifica in the northeast of Indonesia may be due to the dispersive glass eel transport throughout eastern Indonesia. The dynamics of the water flow in eastern Indonesia are heavily influenced by the Indonesia River Flow, where these currents enter the Indonesian waters from the Pacific, flowing into the Indian Ocean via the western route of the Makassar Strait, then exit through the Lombok Strait. In this condition, the current can flow eastward into the Banda Sea. The saltier and denser waters of the South Pacific pass through the Banda Sea, where this mass of water will be mixed (Gardon, 2005). This current flow affects the local climate and helps the distribution of planktonic eggs and larvae.

The Distribution of Anguilla marmorata. The spawning areas that supply glass eels taken from the Dumoga River are not known with certainty. The existence of glass eel $A$. marmorata in the Dumoga River is part of the Japan-Sulawesi panmictic population based on genetic analysis by Minegishi et al., (2008), and originated from the spawning area of the North East Pacific Ocean proposed by Miller et al. (2002 ); (Righton et al., 2012). The spawning area of A. marmorata is found in the northern part of Sulawesi waters (Aoyama et al., 2003; Wouthuyzen et al., 2009) after the capture of a small glass eel between midAugust and late October. Seed of A. marmorata can be found almost year-round at the mouth of the Poigar river, Sulawesi (Arai et al., 1999). A. marmorata has also been found, on the west coast of Papua. This shows the possibility of other spawning areas in eastern Indonesia other than in northern Sulawesi so that in this study glass eel is dominated by $A$. marmorata.

Based on the biological aspects of $A$. marmorata it is known that the current dynamics pattern is due to the effects of water entering from the North Pacific and the South Pacific. In addition, these waters cross the Wallacea line, which affects the pattern of species spread. There are some deep waters in eastern Indonesia that allow spawning, such as the Arafura Sea, Makassar Strait, Flores Sea, Sulawesi Sea, Tomini Bay and Bone Bay. Therefore, more research is needed on the structure of population A. marmorata in Indonesian waters, especially the eastern part of Indonesia.

Analysis of the population structure of A. bicolor pacifica showed no significant genetic differences in the distribution of the South Pacific Ocean (Minegishi et al., 2012). The wide distribution of $A$. bicolor pacifica in the northeast of Indonesia may be due to the dispersive glass eel transport throughout eastern Indonesia. The dynamics of the water flow in eastern Indonesia are heavily influenced by the Indonesia River Flow, where these currents enter the Indonesian waters from the Pacific, flowing into the Indian Ocean via the western route of the Makassar Strait, then exit through the Lombok Strait. In this condition, the current can flow eastward into the Banda Sea. The more salty and denser waters of the South Pacific pass through the Banda Sea, where this mass of water will be mixed (Gardon, 2005). This current flow affects the local climate and helps the distribution of planktonic eggs and larvae.

Distribution of Anguilla sp. The other types of eel (Anguilla sp.) in this research have an ADV range 6-7. However, its genetic is certainly not known yet. There are three species of tropical glass eel known to have anodorsal vertebrate between 6 and 12, which are $A$. celebesensis and A. borneensis (7-10 ADV). The glass eel from A. celebesensis and A. borneensis have been identified in the Makassar Strait (Wouthuyzen et al., 2009). The 
available information indicates that the spawning area of A. borneensis is likely to be in or close to Makassar Strait.

A. celebesensis is one of the endemic tropical eel species in Sulawesi. The glass eel species are collected in two different seasons and in two different regions (Sulawesi Sea and Tomini Bay). Glass eel in Tomini Bay was discovered in May, while leptocephalus in the Sulawesi Sea was discovered in February (Aoyama et al., 2003; Wouthuyzen et al., 2009). However, in a research conducted in April-May, this endemic species was still found in the Dumoga estuary since the spawning and growth area of $A$. celebesensis are considered to be in Tomini Bay. Therefore, it indicates that the migration distance of $A$. celebesensis is the shortest one of the genus Anguilla since the approximate migration distance is $80 \mathrm{~km}$.

In addition to the Sulawesi Sea, the spawning area of $A$. celebesensis is also located in Tomini Bay (Aoyama et al., 2003). At least, the larvae can be carried out from the bay by the water flow that will eventually join the Indonesian Throughflow and enter the Makassar Strait. This suggests that eels, such as A. marmorata and A. celebesensis may have more than one spawning area.

The other A. borneensis endemic tropical species is taken from Celebes Sea (Aoyama et al., 2003). A. borneensis growth habitat is limited to the eastern Borneo and the Celebes Sea. In this research, A. borneensis specimen is allegedly found since the research location has a direct contact with the Celebes Sea and Makassar Strait. The migration distance of A. borneensis glass eel is at least 450-650 km from the spawning area (Aoyama et al., 2003).

The tropical eel has a unique distribution and migration patterns such as short migration distance, short metamorphosis duration, spawning throughout the year and some of them spread widely, while some others spread closely. The spreading behavior pattern is an important factor in the separation of eel types, because, in leptocephalus stadia, the eel will swim passively following the flow pattern. However, the re-migration of the eel depends largely on its ability and oceanographic condition.

The occurrence of abundance variation (absolute and relative) is caused by the combination of several factors discussed by Kuroki et al., (2012). Factors that may affect the uptake of each glass eel species are affected by the survival rate, the time and spawning result as well as the transport of glass eel larvae following the ocean flow as a glass eel and the metamorphosis process into glass eel stage.

Righton et al., (2012) state that the eel migration may be affected by factors related to climate. The survival and migration route of glass eel larvae can be affected by multi-decade trends in ocean circulation and pattern changes affected by the climate. There is a temporal pattern in taking the glass eels in the Dumoga River over a period of years or even decades that cannot be detected based on the short duration of the data. It is also possible that the pattern changes or will change due to the global shift in climate and ocean circulation.

Seen from the biodiversity perspective, the existence of Anguilla sp. species in small quantity with ADV of 6-12 are still considered important to ensure that glass eels survive during the migration. Therefore, it is suggested to let the glass eel of ADV group of 6-12 go and return it to the wild. The spot observation and distribution variability of ADV numbers reinforce the opinion that there may be more than one species with ADV ranges of 6-12 taken from the Dumoga estuary. Furthermore, the difference in glass eel size is due to the presence of two (or more) species and/or the existence of glass eels from different ages (from different spawning activities or even laying spots) taken at the same time.

Three species taken from the Dumoga estuary with ADV numbers in the range of 6-12 are important from biodiversity and biogeography perspective in order to identify the species that actually exist. Identification of glass eels based on DNA from one or more recent species has been developed by Fahmi et al., (2013). Seasonal and annual variability needs to be observed in the recruitment. The sample selection should include full ADV range and fat least few months (ideally over a period of one or more years) to ensure complete identification of existing species. 


\section{CONCLUSION}

During the research period, three species of Dumoga estuary have been collected. The species composition is dominated by Anguilla Marmorata and Anguilla bicolor Pacifica, both of which are commercially valuable. In addition, a species that cannot be accurately identified using ADV and tail pigmentation method was found. However, from the aspects of conservation and biodiversity, it is considered very important. A genetic analysis method is required to identify this species in order to know the whole composition of glass eel species collected from the Dumoga River.

\section{REFERENCES}

1. Arai, T., D. Limbong, T. Otake, K. Tsukamoto. 1999. Metamorphosis and Inshore Migration of Tropical Eels, Anguilla spp. in the Indo-Pacific. Marine Ecology. Progress Series, 182,283-293.

2. Arai T. 2014. Do we protect freshwater eels or do we drive them to extinction? SpringerPlus. 3:534.

3. Aoyama, J., S. Wouthuyzen, M.J. Miller, T. Inagaki and K. Tsukamoto. 2003. ShortDistance Spawning Migration of Tropical Freshwater Eels. Hal.104-108.

4. Aoyama J. 2009. Life History and Evolution of Migration in Catadromous Eels (genus Anguilla). Aqua-BioSci. Monogr. (ABSM) 2: 1-42.

5. Fahmi MR, Solihin DD, Soewardi K, Pouyaud L, Shao Z, Berrebi P. 2013. A novel semimultiplex PCR assay for identification of tropical eels of genus Anguilla in Indone-sian waters. Fisheries Science, 79(2):185-191

6. Fahmi, M.R. 2015. Short Communication: Conservation Genetic of Tropical Eel in Indonesian Waters Based on Population Genetic Study. Balai Riset dan Pengembangan Budidaya Ikan Hias. Masyarakat Biodiversitas Nasional, 1(1): 38-43.

7. Gardon AL. 2005. Oceanography of the Indonesia and their troughflow. Oceanography; 18:4.

8. Ishikawa, S., Katsumi, T., and Mutsumi Nishida. 2004. Genetic Evidence for Multiple Geographic Populations of the Giant Mottled Eel Anguilla marmorata in the Pacific and Indian Oceans. The Ichthyological Society of Japan. Ichthyol Res (2004) 51: 343-353

9. Kuroki M, Miller MJ, Aoyama J, Watanabe S, Yoshinaga T, Tsukamoto K. 2012. Offshore spawning for the newly discovered anguil-lid species Anguilla luzonensis in the Western North Pacific. Pacific Science, 66:497-507.

10. Miller MJ., N. Mochioka, T. Otake, and K. Tsukamoto. 2002. Evidence of a spawning area of Anguilla marmorata in the western North Pacific. Springer-Verlag. Marine Biology 140: 809-814.

11. Minegishi Y, Aoyama J, Tsukamoto K. 2008. Multiple population structure of the giant mottle eel Anguilla marmorata. Mol.Ecol; 17: 3109-3122.

12. Minegishi Y, Gagnaire PA, Aoyama J, Bosc P, Feunteun E, Tsukamoto K, Berrebi P. 2012. Present and past genetic connectivity of the Indo-Pacific tropical eel Anguilla bicolor. J. Biogeogr; 39: 408-420.

13. Novianti, V., 2007. Komposisi Spesies dan Kelimpahan Juvenil Sidat (Anguilla spp.) Yang Memasuki Beberapa Muara Sungai di Perairan Indonesia. Perpustakaan Universitas Andalas.

14. Reveillac E, Gagnaire PA, Finigers L, Berrebi P, Robinet T, Valade, Feunteun E. 2009. Development of Key Using Morphological Character to Distinguish South-Western India Ocean Anguilla Glass Eel. Jurnal Fish Biology. 25:547-572.

15. Righton D, Aarestrup K, Jellyman D, Ebert PS, Van Den Thillart G, Tsukamoto K. 2012. The Anguilla spp. migration problem: 40 million years of evolution and two millennia of speculation. Journal of Fish Bio-logy, 81(2):365-386.

16. Sugeha, H.Y and Suharti R.S., 2008. Discrimination and Distribution of Two Tropical Short-Finned Eels (Anguilla bicolor bicolor and Anguilla bicolor pacifica) in the Indonesian 
Waters. Research Center for Oceanography, Indonesian Institute of Sciences. The Nagisa Westpac Congress: 1-14

17. Sugeha H.Y and Arai, T. 2010. Contrasting Morphology, Genetic, and Recruitment Season of Anguilla marmorata Glass Eels from Northern, Western, and Central Sulawesi Island, Indonesia. IImu Kelautan Vol. 1. ISSN 0853 - 7291. Edisi Khusus: 1 - 19

18. Tesch F.W, Bartsch P, Berg R, Gabriel O, Henderonn IW, Kamastra A, Kloppmann M, Reimer LW, Soffker K, Wirth T. 2003. The Eel. White RJ. penerjemah; Thorpe JE. editor. German (ID). Publishing Company.

19. Watanabe S. 2003. Taxonomy of the freshwater eels genus Anguilla. Schrank, 1798. In: Aida, K., Tsukamoto, K., Yamauchi, K. Eel Biology. Springer-Verlag.Takyo. 3-18.

20. Wouthuyzen S, Aoyama J, Sugeha HY, Miller MJ, Kuroki M, Minegishi Y, Suharti SR and Tsokamoto K. 2009. Seasonality of spawning by tropical anguillid eels around Sulawesi Island, Indonesia. Naturwissenschaften. 